[2] V. N. Urodovskih, Upravlenie riskami predpriyatiya. M.:Vuzovskiy uchebnik: INFRA-M, 2012;

[3] A.Griffit, Sistemyi upravleniya v stroitelstve. Samara: Olimp-Biznes, 2006;

[4] DBN V.3.1-1-2002. (2003). Derzhavni budivelni normy Ukrayiny. Ekspluatatsiya konstruktsiy ta inzhenernogo obladnannya budivel i sporud ta sistem zhittEzabezpechennya. Remont i pidsilennya nesuchih i ogorodzhuvalnih budivelnih konstruktsiy i osnov promislovih budinkiv ta sporud. Derzhavniy komitet Ukrayini z budivnitstva i arhitekturi, 56;

[5] Gogunskiy, V. D., Stanovskaya, I. I., Gurev, I. N. (). Zakon Bushueva - garantiya nepolnoy transformatsii seriynyih proektov v operatsionnuyu deyatelnost. Vostochno-evropeyskiy zhurnal peredovyih tehnologiy. Informatsionnyie tehnologii, Harkov, 4/3 (64), 41 - 44;

[6] Barinov, V. A. (2016). Reinzhiniring: suschnost i metodologiya / Elitarium. Available http://www.ippnou.ru/print/002369/;

[7] Kontora Tehnohimicheskogo zavoda poligraficheskoy kraski i lakov (2016). Available: <http://baltstroi.ru/ru/proekty/kontora_tehnohimicheskogo_zavoda/>.

Література

[1] Е. В. Колесникова, И. И. Становская, "Методы количественной оценки степени трансформации серийной проектной деятельности в операционную,” Інформаційні технології в освіті, науиі та виробнищтві: збірник наукових пращь, вип. 4(5), сс. 32 - 40, 2013;

[2] В. Н. Уродовских, Управление рисками предприятия. М.: Вузовский учебник, ИНФРА-М, 2012;

[3] А. Гриффит, Системы управления в строительстве. Самара: Олимп-Бизнес, 2006;

[4] ДБН В.3.1-1-2002. Державні будівельні норми України. Експлуатація конструкцій та інженерного обладнання будівель і споруд та систем життєзабезпечення. Ремонт і підсилення несучих і огороджувальних будівельних конструкцій і основ промислових будинків та споруд. - К.: Державний комітет України з будівництва i архітектури, 2003. - $56 \mathrm{c}$;

[5] В. Д. Гогунский и др., “Закон Бушуева - гарантия неполной трансформации серийных проектов в операционную деятельность” Восточно-европейский журнал передовых технологий. Информационные технологии, по. 4/3 (64), сс. $41-44,2013$;

[6] В. А. Баринов, (19, June 2006). “Реинжиниринг: сущность и методология” Элитариум [Онлайн]. Режим доступа: http://www.ippnou.ru/print/002369/. [Доступно: Октябрь 8, 2016];

[7] Балт Строй. "Контора Технохимического завода полиграфической краски и лаков," balt-stroi.ru.[Онлайн]. Режим доступа: http://balt-stroi.ru/ru/proekty/kontora_tehnohimicheskogo_zavoda/. [Доступно: Июль 14, 2016].

\title{
AUTOMATIC REGULATOR FOR NON-STATIONARY OBJECTS WITH AN INCREASED RANGE OF NORMAL OPERATION
}

\author{
A. I. Pavlov ${ }^{1}$ \\ ${ }^{1}$ Odessa National Academy of food technologies, Odessa \\ Copyright (C 2014 by author and the journal “Automation technological and business - processes". \\ This work is licensed under the Creative Commons Attribution International License (CC BY). \\ http://creativecommons.org/licenses/by/4.0/
}

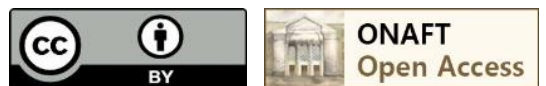

Abstract: Many objects automatic control unsteady. This is manifested in the change of their parameters. Therefore, 
periodically adjust the required parameters of the controller. This work is usually carried out rarely. For a long time, regulators are working with is not the optimal settings. The consequence of this is the low quality of many industrial control systems. The solution problem is the use of robust controllers. Explores the possibility of increasing the survivability of automatic control systems by expanding the area of their normal work. This is achieved by using an artificial neural network simple structure. The method is based on the cooperative effect of neural structures. In this block diagram of the controller is very simple. Such control effectively compensates the coordinate perturbations if they act on the control channel.

Key words: Control system, object, model, MatLab, Simulink.

\section{Problem statement}

In industry, the object of regulation (OR) is most often is a technological apparatus. To the strong influence of parametric perturbations. Unfortunately, PI and PID controllers compensate the changes of OR parameters insufficiently and that is why the adjustment of these controllers is required. As for Multi-Loop Automatic Control Systems (ACS), the quantity of which increases, adjustment of controllers is a difficult engineering challenge. If we add that the parameters of most OR change fast to this, ensuring the controllers' parameters compliance with OR parameters becomes a nearly impossible task (moreover if dealing with multidimensional OR with a great number of interconnections) with all consequences resulting from that fact to the extent of control quality decrease.

Problem solution

One of the solutions for such a situation is an increase of ACS durability. That term requires specification. Within the scope of this article it can be construed as follows: ACS durability is its ability to provide execution of the assigned control tasks (compliance with regulations) during a long time with the OR being affected with parametrical and coordinate disturbances without the necessity of conduction of adjustment works at controllers.

It is possible to decrease the acuteness of the specified issue by using hybrid controllers. That term requires specification. The hybrid controller shall be construed as that one the structure of which applies fuzzy logics algorithms and (or) artificial neural networks together with common dynamic integrating units and, if necessary, differentiators.

There are lots of variants of construction of hybrid controllers. What index should be used for the most objective comparison of ACS with various controllers including common control algorithms? It appears that ACS durability can be such an index.

The quantitative assessment of ACS durability can be performed by comparing the Normal Operating Limits (NOL) of various controllers. What is NOL of a controller?

We shall proceed from the fact that upon development of a controller's structure one needs to use the advantages provided by artificial neural networks, namely the expressed cooperativity, at the same time avoiding the difficultness of software implementation within the industrial controller. It is such "balance of interests" that is native to the controller structure described below.

The figure 1 shows the structure diagram of stabilizing ACS simulating model the hybrid controller of which uses a very simple artificial neural network. The model is realized in the environment of MATLAB with use of software packages of Simulink.

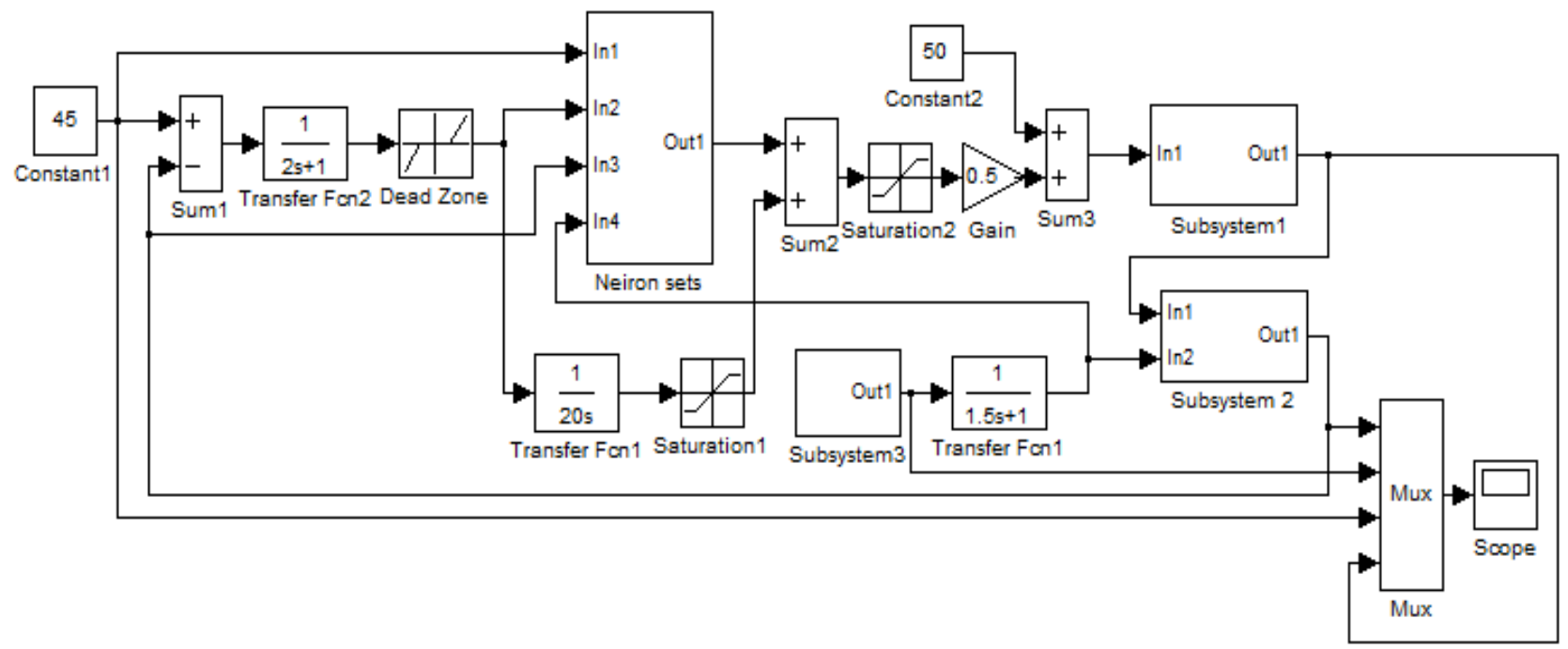

Fig. 1 - Model of automatic control system in Simulink

The parameters of control interaction indexes of manually taught neural network used for determination of NOL of the controller shall have the numerical values in vector mode: $\mathrm{k} 1=-0.2 ; \mathrm{k} 2=2.8 ; \mathrm{k} 3=0.5 ; \mathrm{k} 4=-2$. It can be expressed in vector notation as follows:

$$
\mathrm{U}=\mathrm{f}[(\mathrm{k} 1 \mathrm{x} 1+\mathrm{k} 2 \mathrm{x} 2+\mathrm{k} 3 \times 3+\mathrm{k} 4 \mathrm{x} 4)] \mathrm{k} 5=\mathrm{f}[(-0.2 \times 1+2.8 \times 2+0.5 \times 3-2 \times 4)] 0.75,
$$


here $\mathrm{x} 1, \mathrm{x} 2, \mathrm{x} 3, \mathrm{x} 4$ are signals of adjuster, regulated coordinate sensor, loop dynamical error and coordinate disturbance. Activation function is lineal with limitations; coefficient of proportionality $\mathrm{k} 5=0.75$.

Appointment and parameters of some elements of the operating subsystem of the ACS model demand probably explanations. So, in a chain of formation of a dynamic error of regulation links, traditional for regulators, are used: the elementary passive filter (aperiodic link of the first order) and «tolerance zone». It is obvious that parameters of these links have to will be defined, in each case of real OR, according to the famous recommendations and techniques.

Subsystem1 displays dynamic properties of the electromotive executive mechanism (EEM) of constant speed of proportional action (fig. 2).

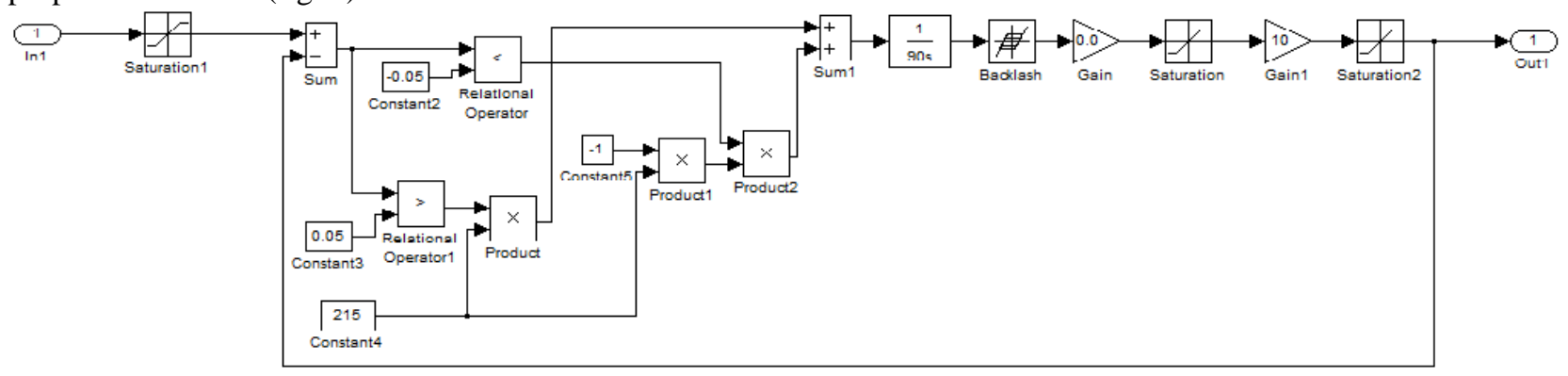

Fig. 2 - Dynamic properties of the electromotive executive mechanism of constant speed of proportional action

Subsystem 2 displays static and dynamic properties of the OR. The throughput characteristic of the regulatory body adopted logarithmic. The structure of the simulation model OR corresponds to the aperiodic link of second order with transport delay.

In essence the structure of the regulator corresponds to PI-algorithm, with that main difference that his proportional part has neural structure. The second difference is that the correction control signal is carried out by coordinate perturbation.

The normal working area (NWA) of the suggested hybrid regulator is presented at the figures 3 and 4 .

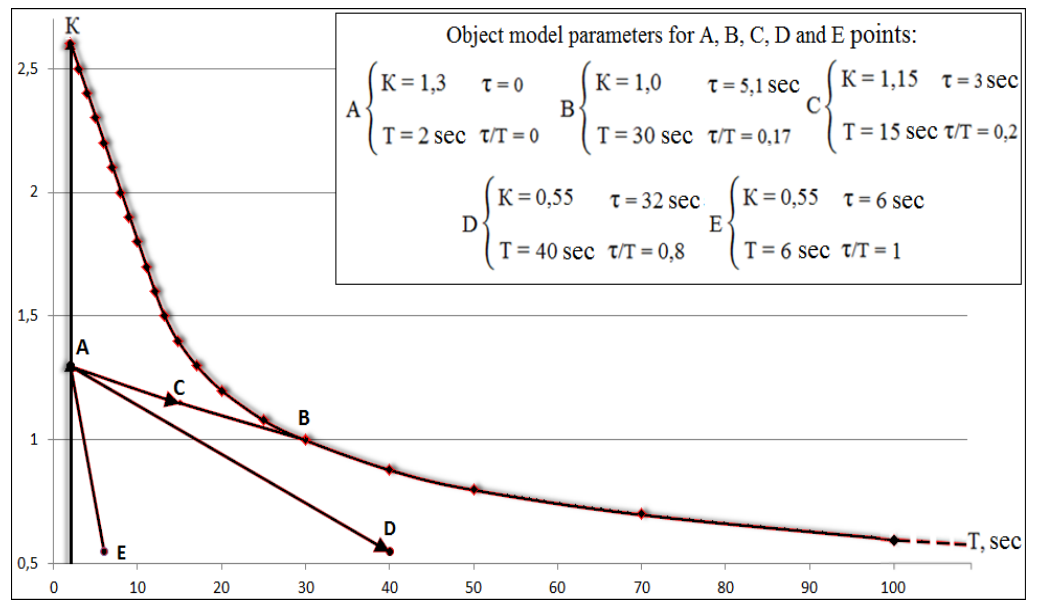

Fig. 3 - The normal working area of the suggested hybrid regulator (coordinate system T - K)

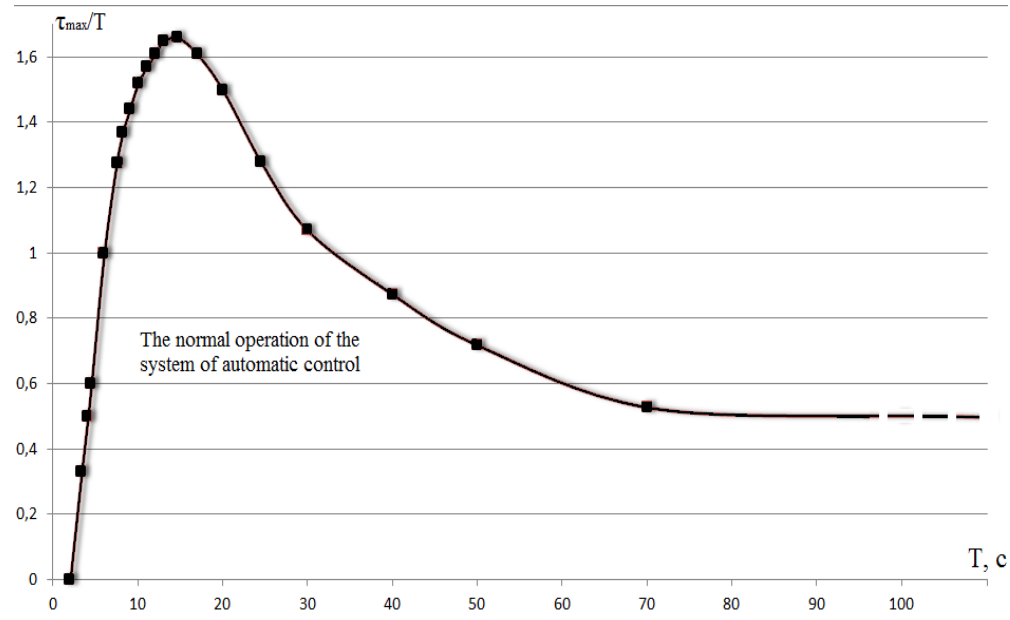

Fig. 4 - The normal working of the suggested hybrid regulator (coordinate system $\mathbf{T}-\tau / \mathrm{T})$ 
Besides, there is shown the key direction of possible changing of OR parameters. The segment of straight lines $\mathrm{AB}$, AD, $\mathrm{AE}$ at this figure shows quite typical directions (trends) of OR parameters changings, but not a law of its dynamics: changing of the values $K, \tau, T, \tau / T$ is non-stationary stochastic process is as a result of a set, generally objective factors those change influence on OR.

Graphics of results of modeling with imitative model parameters of OR those equals to points A, B, C, D and E in application option of membrane executive mechanism are presented at the figures 5, 6, 7,8 and 9 and speak for themselves. Comments are excessive as they say.

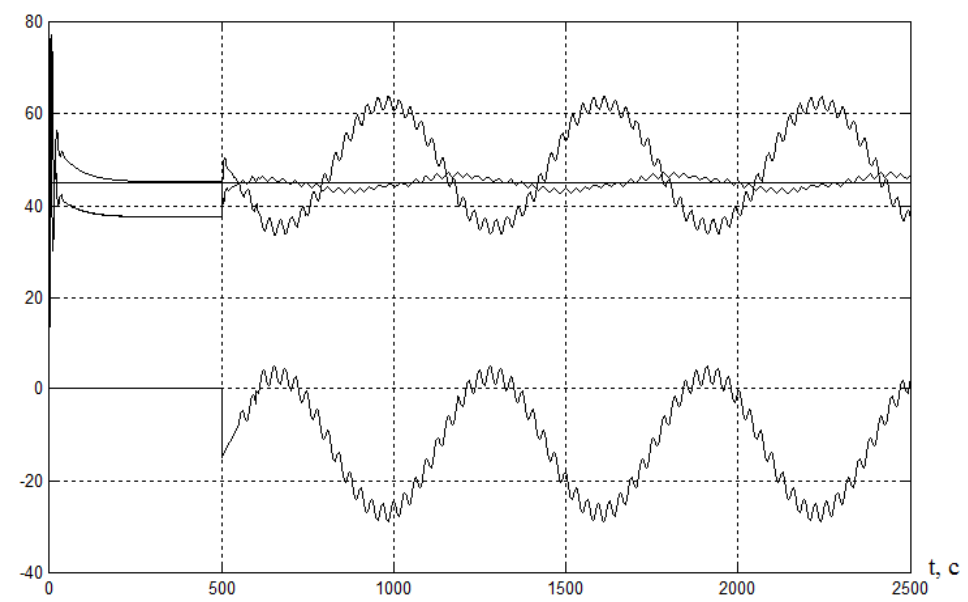

Fig. 5 - Modeling results control system $(K=1.3, \tau=0, T=2 \sec )$

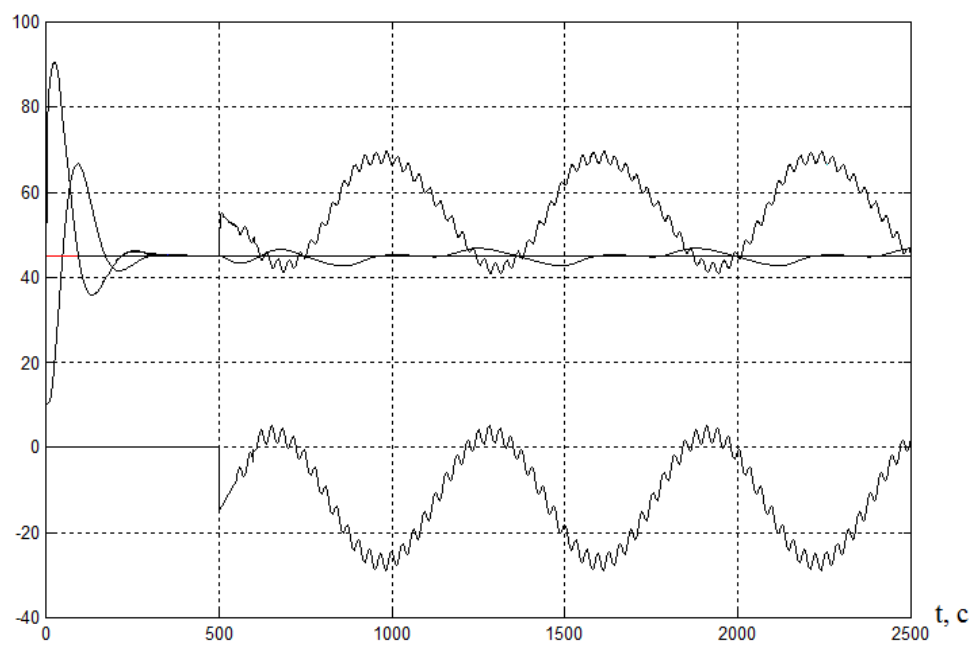

Fig. 6 - Modeling results control system $(K=1.0, \tau=5.1 \mathrm{sec}, T=30 \mathrm{sec})$

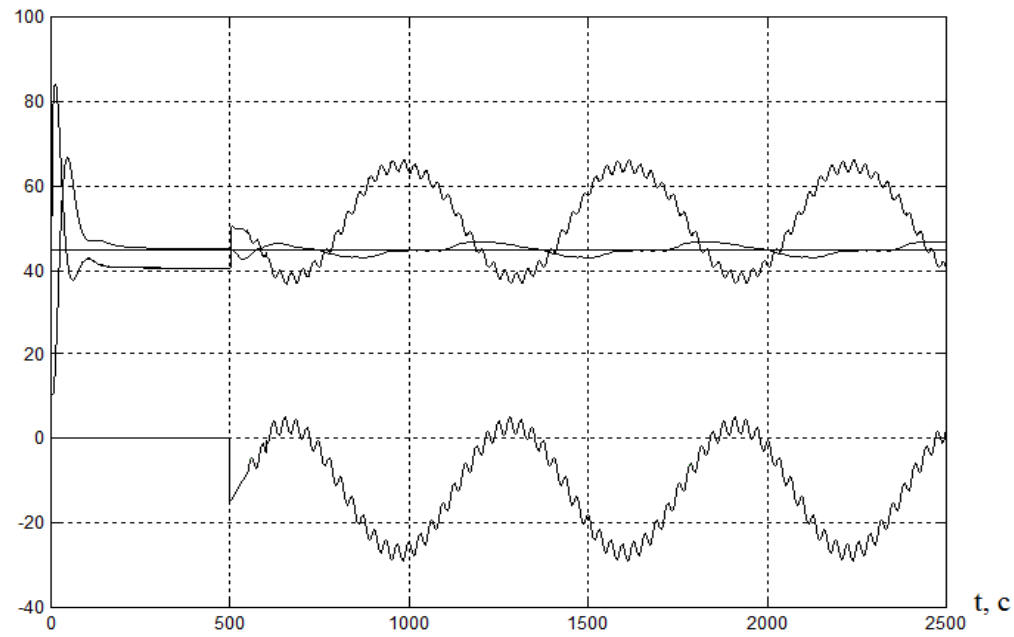

Fig. 7 - Modeling results control system $(K=1.15, \tau=3 \mathrm{sec}, T=15 \mathrm{sec})$ 


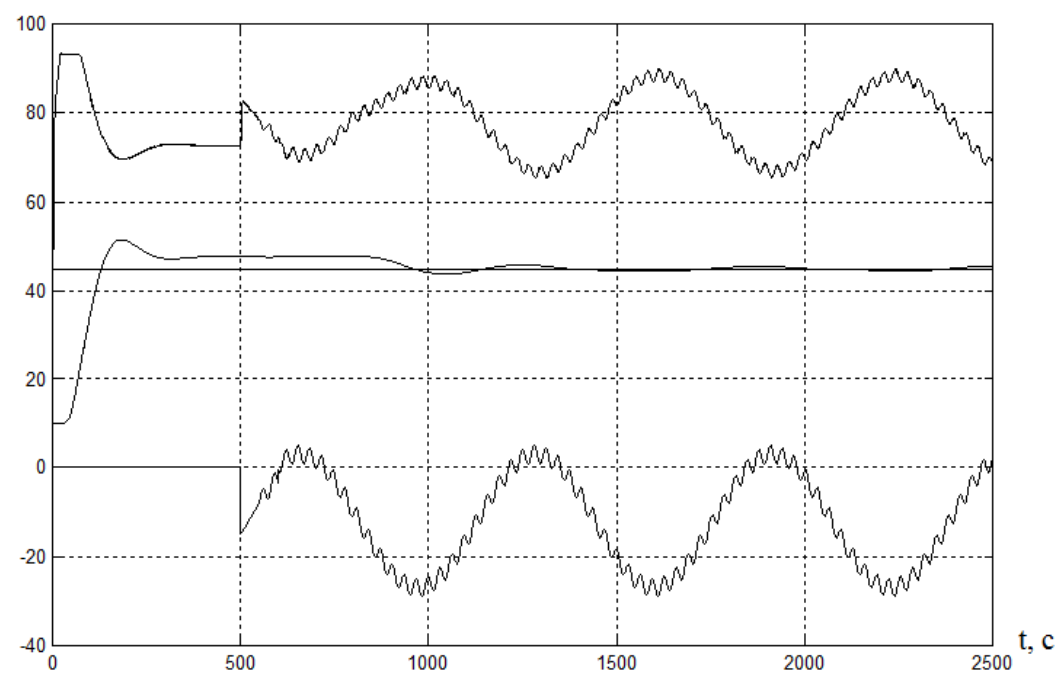

Fig. 8 - Modeling results control system $(K=0.55, \tau=32 \mathrm{sec}, T=40 \mathrm{sec})$

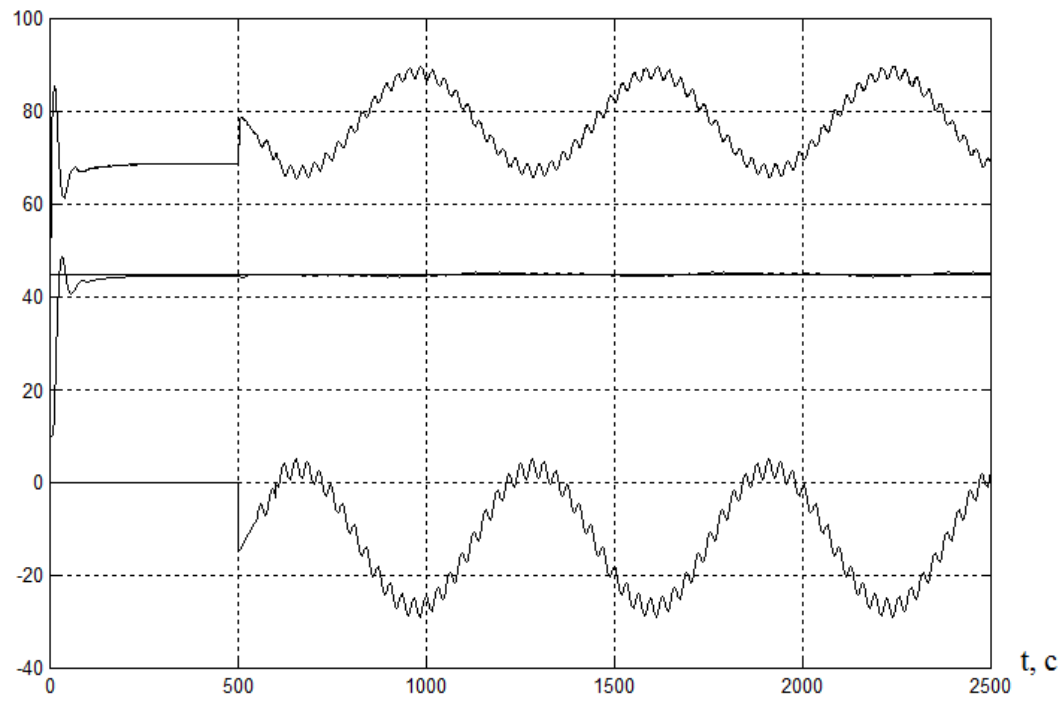

Fig. 9 - Modeling results control system $(K=0.55, \tau=6 \mathrm{sec}, \mathrm{T}=6 \mathrm{sec})$

As a criterion for definition of NBA for considered controller, viz. for finding it compass, was accepted value of dynamic inaccuracy of control loop as $5 \%$. Here, I want to mark, that if we use pneumatic diaphragm actuator NBA wider, because they have higher dynamic properties.

In the simulation we examine case, when coordinate perturbation function by control channel and present itself, as a sum of 2 harmonic signals, they differ by its amplitude and frequency. All options of the controller and execution unit by simulating don't change.

\section{Conclusions}

In works [7, 8, 9] represents simulation models SAR with unsteady objects with PI-controller and 2 kinds of hybrid controllers. In [7] we could see dynamical correction of coefficient transferring controller by its changing value of thermal flow OR. In this work, firstly was determine value ONR controller. In [8] also was determine ONR, comparing with ONR from work [7] showing, that its square higher on $25 \%$, but the biggest ONR has controller from [9].

Changing the coefficients of the simulation model OR characterizing wear real object, does not reduce the quality of ACS management. Moreover, the quality of regulation increases!

\section{References}

[1] А. И. Павлов, “Нейронная система регулирования,” Научные труды ОНАПТ, вып. 31, ном. 2, сс. 72-77, 2007;

[2] А. И. Павлов, “Нейронная система регулирования высокой динамической точности,” Hayчные труды OHAПT, вып. 33, сс. 64-69, 2008;

[3] А. И. Павлов, “Технология проектирования нейронных регуляторов,” Автоматизация технологических и бизнес-процессов, ном. 4, сс. 15-20, 2010;

[4] А. И. Павлов, “Повышение эффективности управляющих воздействий автоматических регуляторов,” Автоматизация технологических и бизнес-процессов, ном. 5, 6, сс. 31-37, 2011; 
[5] А. И. Павлов, “Повышение адекватности имитационных моделей нелинейных диссипативных объектов,” Автоматизация технологических и бизнес-процессов, ном. 17, сс. 4-7, 2014;

[6] А. И. Павлов, “Виртуальный стенд для определения оптимального по быстродействию исполнительного устройства," Автоматизация технологических и бизнес-процессов, вып. 6, ном. 4, сс. 130-137, 2014;

[7] А. И. Павлов, “Динамическая коррекция коэффициента передачи пропорционально-интегрального регулятора,” Автоматизация технологических и бизнес-процессов, вып. 7, ном. 1, сс. 31-34, 2015;

[8] А. И. Павлов, “Система автоматического регулирования температуры нестационарного объекта,” Автоматизация технологических и бизнес-процессов, вып. 7, ном. 2, сс. 31-34, 2015;

[9] А. И. Павлов, “Каскадная система автоматического регулирования с нестационарным объектом," Автоматизация технологических и бизнес-процессов, вып. 8, ном. 3, сс. 4-9, 2015;

[10] А. И. Павлов, “Простой ПИ-подобный регулятор с континуальной логикой для нестационарных объектов,” Автоматизация технологических и бизнес-процессов, вып. 9, ном. 1, сс. 65-71, 2016.

\title{
ESTIMATION OF THE WIDTH OF THE STATIONARY DETONATION WAVE IN THE MODEL OF ZEL'DOVICH- NEUMANN-DÖRING
}

\author{
A. S. Tityapkin ${ }^{1}$, V. E. Volkov ${ }^{2}$ \\ ${ }^{1}$ Ukrainian Scientific Center of Ecology of the Sea, Odessa \\ ${ }^{2}$ Odessa National Academy of food technologies, Odessa \\ Copyright (C) 2014 by author and the journal "Automation technological and business - processes". \\ This work is licensed under the Creative Commons Attribution International License (CC BY). \\ http://creativecommons.org/licenses/by/4.0/
}

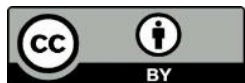

ONAFT

Open Access

Abstract: The models of Chapman-Jouget and Zel'dovich-Neumann-Döring are considered to estimate the width of a detonation wave in gas mixtures. Improved software package was developed earlier. The calculations of stationary detonation wave width are in good agreement with the experimental data. Estimation of the stationary detonation wave width is important for the detonation control.

Key words: The detonation wave, the width of the stationary detonation wave, ZND model, software complex, control.

From the viewpoint of explosion protection the most important problems are the detonation initiation, the structure of detonation waves, the detonation limits (on concentration and initial pressure), and the limiting detonation regime (spin and a gallop). All of these problems are connected with the problem of stability of one-dimensional stationary detonation wave. A detailed analysis of the detonation wave instability allows to calculate the structure of multifront (cellular) detonation, estimating the cell size by the wave length of perturbations with maximum velocity for amplitude increase. The inversely proportional dependence between the detonation cell size and the initial combustible mixture pressure allows to control the detonation process, which is important for solving practical problems of explosion. For these cases a problem of estimation for a detonation wave width, including a chemical reaction zone and / or the induction zone, is important, especially if there are no experimental data. Solving of this problem is the purpose of this study.

V.A. Michelson [1] was the first who gave physical explanation for observations of detonations in gas mixtures. Chapman and Jouget [2, 3] developed idea about detonation wave as a shock wave with the small time of chemical transformation directly in the front. Reaction zone was considered simply as a surface of discontinuity. Their hypothesis that the velocity of detonation products is equal to the local velocity of sound closed the set of equations consisting of conservation laws and the 